\title{
27 Kasım 2016 Dünya Yaratıcı Drama Günü Ulusal Bildirgesi
}

Bir dünya düşlüyorum...

İnsanlar doğadaki tüm renkleri, tınıları resme ve müziğe katmışlar, heyecan, mutluluklarını sözcüklerle yoğurmuşlar, aralarında milliyet, cinsiyet, ırk, yaş gözetmeksizin hep birlikte oyunlar oynuyorlar. Belki aynı dili konuşmuyorlar ama bir ortak dilleri var; o da SANAT.

Ki o da evrensel.

Yaşadığım dünya ise şöyle: sevgi bağımlılığa dönüşmüş.

Dillerde 'huzur' sözcüğü var ama görülen ve hissedilen öfke.

Neşe ve mutluluk yerini hırslara bırakmış.

Hoşgörü, uyum, işbirliği ego olmadan anılamaz olmuş adeta.

Peki hayallerimi gerçekleştirmeme kimler, neler, nasıl engel?

$\mathrm{Bu}$ hızla akıp giden, kirlenen zamanda gerçek dünyaya kayıtsızca bakmalı mı insan? Yoksa bakıp gördüklerini, duyup dinlediklerini, algıladıklarını, anlamlandırıp sorgulayıp düşünerek yaratarak yeni ifade biçimleri mi aramalı?

Kim bilir; belki de o aradığım yeni ifade biçimleri kurgusal dünyada gizlidir. Gerçek dünyadan kurgusal dünyaya geçişteki köprüde hayatı deneyimleyebilir, kendime yeni alternatifler yaratabilir, dış dünyayla empati kurabilir, gerçekten KİM olduğumu, gerçek potansiyalimi keşfedebilir, sorularımı yanıtlara, sorunlarımı çözümlere dönüştürebilirim.

Drama - Tiyatro - Eğitim; Sanatla iç içe yoğrulup “İyi - Güzel ve Doğru”nun kapısını açan anahtarlardır. Bu anahtarlarsa gizli, sırlarla dolu bir hazine sandığının içinde değil, yanıbaşımızda hatta avuçlarımızdadır.

“İyi - Güzel ve Doğru”ya giden yolda sorgulamak, ayırt etmek, cesaret ve kararlılık göstermek, uyumlu olmak yolumuzu aydınlatan fenerler gibidir.

Karanlığı aydınlatan bu fenerler farkındalıksa, bu farkındalıklarla oynanan oyunlara herkes katılmak ister. Herkesin katılımıyla zenginleşen oyunsa dünyayı dönüştürmeye başlar bile... Derken aydınlık büyür, genişler, çoğalır...

Dünya Yaratıcı Drama Günü'nde ve takip eden tüm günlerde sadece sözcüklerle değil, eylemlerle, erdemlerle, sanatla düşlediğimiz dünyayı yaratmak, keyif, neşe ve mutlulukla oynayacağımız oyunlarda buluşmak ümidiyle...

Her şey yok olabilir ama umut asla...

Sayg1 ve sevgi ile..

\section{Nalan Olgun}

Çağdaş Drama Derneği Üyesi ve Eğitmeni 